Western North American Naturalist 68(2), (C) 2008, pp. 231-240

\title{
INFLUENCE OF SOIL AND SITE CHARACTERISTICS ON PALOUSE PRAIRIE PLANT COMMUNITIES
}

\author{
Thor Hanson ${ }^{1,4}$, Yaniria Sánchez-de León ${ }^{2}$, Jodi Johnson-Maynard ${ }^{3}$, and Steve Brunsfeld ${ }^{1}$
}

\begin{abstract}
The structure of grassland communities can vary widely in response to heterogeneous habitat variables. In this study we document plant communities, soil types, and site characteristics for 12 Palouse prairie remnants in southeastern Washington and northern Idaho. We used general linear models to test the predictive value of 6 biophysical variables (slope, aspect, distance from edge, edge type, vegetation structure, and soil type) on 3 plant community metrics: species richness, Simpson's diversity index, and the dominance of exotic species. From full models including all variables, we used Akaike's information criterion (AIC) to select the best model for each metric. Aspect and vegetation structure were significant predictors of species richness $\left(R^{2}=0.08\right)$ and diversity $\left(R^{2}=0.09\right)$, while aspect, soil type, distance from edge, and edge type (type of adjacent matrix habitat) influenced the dominance of exotic species $\left(R^{2}=0.28\right)$. Additional soil sampling determined that the depth to a restrictive layer also had significant impacts on the dominance of exotic species $\left(R^{2}=0.31\right)$. This study confirms that biophysical characteristics influence Palouse prairie plant communities and may help set research and conservation priorities for isolated and uninventoried remnants.
\end{abstract}

Key words: Palouse prairie, plant communities, soil types, biophysical characteristics, soil depth, diversity, exotic species, general linear models.

Habitat heterogeneity exerts a strong influence on the structure of biotic communities, affecting species composition and diversity at multiple scales (Greig-Smith 1979, Steiner and Kohler 2003, Bennett et al. 2006). Individual species respond to a range of biophysical variables, often forming distinct assemblages where their habitat suitability overlaps (Fischer et al. 2004). Though patterns vary by taxa (Atauri and de Lucio 2001), physically diverse landscapes typically support a wider range of communities, increasing levels of regional diversity (Pino et al. 2000, Wilsey et al. 2005). Even subtle changes in environmental variables can shift local species composition (Huenneke et al. 1990, Steinauer and Collins 1995, Bowles et al. 2005) and lead to higher site-level diversity. Finding links between biophysical characteristics and species composition is a fundamental aspect of understanding and managing biodiversity in complex landscapes.

Worldwide declines in native grasslands have led to increased research and conservation planning within these habitats (Samson and Knopf 1996, White et al. 2000). Recent studies of North American prairies have focused on relict populations (Wilsey et al. 2005), invasive exotic species (Sperber et al. 2003, Vinton and Georgen 2006), and restoration efforts (McLachlan and Knispel 2005, Polley et al. 2005). Links between biophysical variables and species assemblages have been shown across climatic clines (Brye et al. 2004) and among sites with different topography and geomorphology (Wilsey et al. 2005). Interactions between plants and soil characteristics have received considerable attention (reviewed in Burke et al. 1998), with trends showing that water availability, nutrient levels, and soil depth can be significant predictors of plant community composition (Bliss and Cox 1964, Wilson et al. 1996, Baer et al. 2005) and the prevalence of invasive exotic species (Vinton and Georgen 2006). In a study of Iowa's tallgrass prairie, Wilsey et al. (2005) found that differences in topography and soil types contributed to high differentiation among patches and that even very small remnants $(<1.5 \mathrm{ha})$ could harbor substantial levels of regional native plant diversity. Patterns of plant diversity can be very

${ }^{1}$ Department of Forest Resources, Box 441133, University of Idaho, Moscow, ID 83844-1133.

${ }^{2}$ Department of Biological Sciences (MC 066), College of Liberal Arts and Sciences, 845 West Taylor Street, University of Illinois at Chicago, Chicago, IL 60607-7060.

3Division of Soil and Land Resources, Department of Plant, Soil and Entomological Sciences, Box 442339, University of Idaho, Moscow, ID 83844-2339.

${ }^{4}$ E-mail: thor@rockisland.com 
site-specific (Greig-Smith 1979), however, and the influence of biophysical variables merits further research in communities of high conservation value.

The Palouse prairie of southeastern Washington and northern Idaho has been called one of the most endangered ecosystems in North America (Noss et al. 1997). Defined by its rolling hills, moderate climate, and a vegetation community of bunchgrasses, forbs, and shrubs (Daubenmire 1970), the region suffered a rapid and almost complete conversion to commercial agriculture in the late 19th and early 20th centuries. As much as $99.9 \%$ of the original prairie was lost, with remnants persisting primarily on steep, untilled slopes, rocky ridgetops, rocky stream channels, and field margins, where they still face threats from development, off-road vehicle use, and invasive species (Lichthardt and Moseley 1997). In a reanalysis of 35- to 50-year-old permanent transects, Klepeis (2001) noted significant declines in native species cover and frequency and corresponding increases in exotic species within several Palouse prairie remnants, particularly for graminoids. Nascent conservation efforts include restoration and public outreach (Weddell and Lichthardt 1998, Weddell 2001), but the remaining habitat is largely undescribed and is scattered in small patches across privately held farmland. Understanding the influence of biophysical characteristics on plant diversity offers a means to predict habitat quality and set research and conservation priorities for these important but uncatalogued prairie patches.

Here we examine the influence of soil and site characteristics on both plant diversity and dominance of exotic species in 12 Palouse prairie remnants. We test the hypothesis that biophysical metrics (e.g., soil type, slope, aspect, vegetation structure) predict plant community characteristics (species richness, Simpson's diversity index, and dominance of exotic species), and we use model testing to identify the factors associated with high native plant diversity. The relationship between soil type and plant communities is explored in further detail, testing the hypothesis that several readily measured soil characteristics (e.g., depth of the A-horizon, depth to restrictive layer) predict species richness, diversity, and dominance of exotics. The potential application of these results to Palouse prairie conservation is also discussed.

\section{Methods}

Study Area

Ecoregional descriptions of the Palouse often include nearby river canyons and shrubsteppe habitat stretching far into eastern Washington (Noss et al. 1997). Here we focus on the biophysical heartland of the Palouse prairie, an area of rolling hills confined to southeastern Washington and the adjacent Idaho panhandle, where wind-blown loess accumulated in thick, hilly deposits throughout the interglacial periods of the Pleistocene (McDonald and Busacca 1988). Derived from the sediments of postglacial lakes and flooding, this loess gave rise to deep, productive topsoil and a native plant community of bunchgrass prairies interspersed with wetlands and patches of forest. The major prairie community has been described as a Symphorocarpus alba / Festuca idahoensis association (Daubenmire 1970), with the shrub $S$. alba as the dominant woody species and $F$. idahoensis the dominant bunchgrass. The bunchgrass Pseudoroegneria spicata (Agropyron spicatum) is considered a common codominant grass in this system. The soil and climatic conditions favorable for native grasses, however, are also ideal for the production of grains. Conversion to agriculture was swift and nearly complete following European settlement, and today the Palouse is a working landscape dominated by large commercial farms. Extant prairie is limited to small, isolated patches on steep, untilled slopes, rocky ridgetops, stream channels, and field margins, as well as pioneer cemeteries and other historical sites (Lichthardt and Moseley 1997, Weddell and Lichthardt 1998). Little is known about the original plant and animal communities, and the distribution and condition of the remaining patches are poorly understood.

\section{Study Sites}

Twelve prairie remnants in Whitman County, Washington, and Latah County, Idaho, were sampled in this study. Since most prairie patches lie on private land, site selection was determined in part by permission for access. While not a random sample, the sites represent a range of sizes $(1.2-165.4 \mathrm{ha})$, slopes $\left(0^{\circ}-32^{\circ}\right)$, and settings (e.g., ridge-tops, field slopes), including 4 different matrix types (adjacent habitats) and 9 distinct soil series (Table 1). Plant data were collected during the 


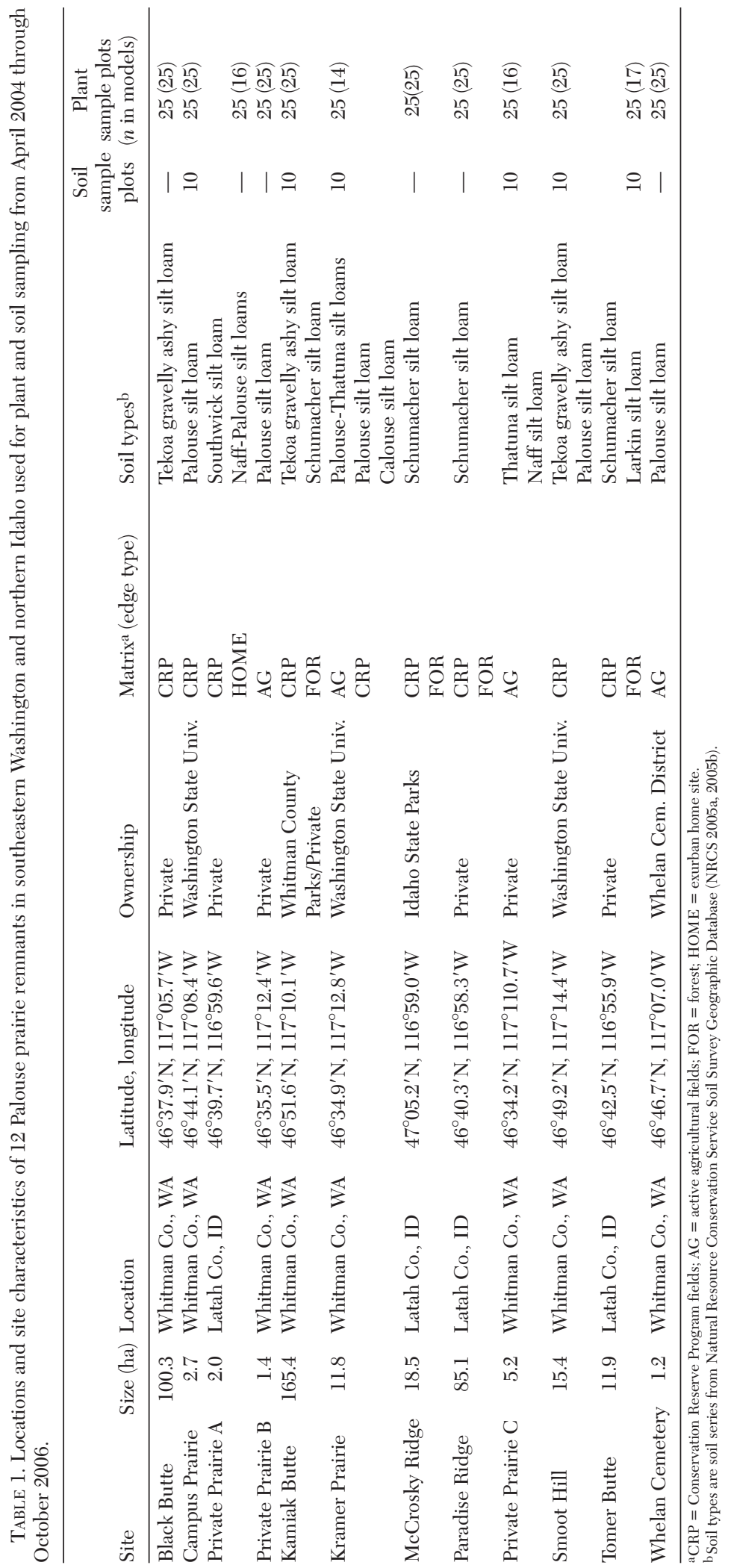


peak flowering period (April-June) in 2004 and 2005. Soil data were collected in September and October 2006.

\section{Plant Communities and Biophysical Characteristics}

Within each prairie remnant, twenty-five $50 \times 20$-cm plots were randomly located and mapped using a Garmin GPS unit. Percent cover was recorded for every species present in each plot frame, following the methods standardized by Daubenmire (1959). We identified specimens in the field, or collected and pressed them for comparison with herbarium specimens. From the species occurrences and percent cover estimates, we calculated 3 plant community metrics for each of the 300 total plots: species richness, Simpson's diversity index (Simpson 1949), and dominance of exotic species (proportion of total cover). Exotic species were defined as any species not native to the Palouse region; we did not further define which of the exotics were considered invasive.

Biophysical characteristics recorded for each plot included slope, aspect, distance from edge, edge type (defined as the closest adjacent matrix habitat: active agricultural field, forest, exurban home site, or fields planted in nonnative grasses as part of the Conservation Reserve Program [CRP]), and vegetation structure variable based on the dominant vegetation type: grass/forb, low-shrub (woody species $<0.5$ m, e.g., Symphorocarpus alba), or high-shrub (woody species $>0.5 \mathrm{~m}$, e.g., Rosa nutkana, Crataegus douglasii). Soil series for each plot were determined from the Natural Resource Conservation Service Soil Survey Geographic Databases for Latah, Idaho, and Whitman, Washington, counties (NRCS 2005a, 2005b). A soil series is the lowest and most specific category of the soil classification system (soil taxonomy) used in the United States, and it groups similar soil pedons that are closely associated in the landscape based on shared soil profile properties and horizons. In the Soil Survey, soil series are mapped within soil mapping units at a scale of approximately 1:20,000 (Soil Survey Division Staff 1993, Buol et al. 2003). For simplicity, however, we refer to series as "soil types" for the remainder of this document.

\section{Additional Soil Characteristics}

Additional soil data were collected at 6 sites, chosen to include multiple examples of the 4 most common soil types (Palouse, Schumacher, Tekoa, and Thatuna silt loams; NRCS 2005a, $2005 \mathrm{~b})$. Ten plant community sample plots were relocated at each site with a Garmin GPS unit. For each plot we recorded the presence of rocks (percent cover within a $50 \times 50$-cm area) at the surface, and sampled the soil with a 7$\mathrm{cm}$-diameter auger to a depth of $50 \mathrm{~cm}$. From the soil sample we determined the depth to restrictive layer (layer that would impede root growth) and the type of restrictive layer (rock or bedrock contact, dense layer enriched in clay, or unknown). We also noted the depth of the A-horizon, defined as the depth to change in soil color and structure.

\section{Data Analysis}

General linear models (GLMs) were used to estimate the effects of biophysical characteristics on plot-level species richness, Simpson's diversity index, and dominance of exotic species for the 263 plots with sufficient sample size for the soil type variable (see Results). For each of the 3 response variables, the full model included soil type, edge type, and vegetation structure as categorical variables. We used the cosine of aspect as a continuous variable to represent the important difference in solar inputs between north- and south-facing orientation. Slope and distance from edge were also included as continuous variables and we added an interaction term for distance from edge and edge type. From the full model we used Akaike's information criterion (AIC; Akaike 1974) to test reduced models and find the most efficient fit to the data. AIC evaluates each model using the equation $\mathrm{AIC}=n\{\ln (\mathrm{SSE} / n)\}$ $+2 p$, where $n$ is the number of plots, SSE is the model's error sum of squares (goodnessof-fit), and $p$ is the number of parameters in the model. It gauges each model's goodnessof-fit in relation to its number of parameters, allowing one to remove superfluous terms from the full model until the most efficient and applicable combination is identified (Akaike 1974). To compare among the categorical variables, a least square means function (2001) was added to each best model, using the TukeyKramer adjustment for multiple comparisons (Tukey 1953, Kramer 1956).

For the 60 plots with additional soil data, we fitted new linear models to test the predictive value of soil characteristics alone. These models included soil type as above, with ordinal 
TABLE 2. Species richness, Simpson's diversity index (Simpson 1949), and dominance of exotic species (i.e., proportion of total plant cover attributed to the nonnative species) from 263 vegetation plots at 12 Palouse prairie remnants in southeastern Washington and northern Idaho, sampled in April-June 2004 and 2005. Means are calculated for 3 categorical biophysical variables: soil type, habitat structure, and edge type (nearest adjacent habitat). Standard deviations are in parentheses. Entries in bold are significantly different $(P<0.05)$ from all others in class based on least-square means analysis in best general linear models.

\begin{tabular}{|c|c|c|c|c|}
\hline Biophysical variable & $\begin{array}{c}n \\
\text { (\# plots) }\end{array}$ & $\begin{array}{c}\text { Species } \\
\text { richness }(s)\end{array}$ & $\begin{array}{l}\text { Simpson’s } \\
\text { diversity }(s)\end{array}$ & $\begin{array}{c}\text { Dominance of } \\
\text { exotic species }(s)\end{array}$ \\
\hline \multicolumn{5}{|l|}{ Soil type } \\
\hline Palouse silt loam & 88 & $10.68(3.75)$ & $0.72(0.15)$ & $0.20(0.23)$ \\
\hline Schumacher silt loam & 76 & $10.93(2.89)$ & $0.75(0.14)$ & $0.41(0.28)$ \\
\hline Southwick silt loam & 16 & $9.94(3.19)$ & $0.73(0.16)$ & $0.15(0.20)$ \\
\hline Tekoa gravelly ashy silt loam & 59 & $10.23(3.20)$ & $0.71(0.15)$ & $0.22(0.20)$ \\
\hline Thatuna silt loam & 24 & $9.71(2.85)$ & $0.73(0.11)$ & $0.06(0.07)$ \\
\hline \multicolumn{5}{|l|}{ Habitat structure } \\
\hline Grass/forb dominated & 199 & $10.97(3.11)$ & $0.75(0.13)$ & $0.28(0.27)$ \\
\hline Low shrub dominated & 47 & $9.38(3.04)$ & $0.68(0.14)$ & $0.16(0.13)$ \\
\hline High shrub dominated & 17 & $8.13(4.43)$ & $0.63(0.21)$ & $0.15(0.27)$ \\
\hline \multicolumn{5}{|l|}{ Edge type (nearest adjacent habitat) } \\
\hline Conservation Reserve Program field & 123 & $10.66(3.44)$ & $0.73(0.14)$ & $0.27(0.23)$ \\
\hline Agricultural field (active) & 75 & $10.71(3.51)$ & $0.73(0.15)$ & $0.17(0.23)$ \\
\hline Forest & 61 & $10.00(2.61)$ & $0.73(0.13)$ & $0.31(0.30)$ \\
\hline Exurban home site & 4 & $10.75(3.86)$ & $0.73(0.15)$ & $0.33(0.33)$ \\
\hline
\end{tabular}

variables in 10-cm increments for depth of Ahorizon and depth to restrictive layer $(0-10$ $\mathrm{cm}, 11-20 \mathrm{~cm}, 21-30 \mathrm{~cm}, 31-40 \mathrm{~cm}, 41-50 \mathrm{~cm}$, $>50 \mathrm{~cm}$ ). The percentage of visible rock fragments in the surface layer was included as a continuous variable, and we again used AIC to test and select the best models. Though we collected data on the depth to 1st color change and the type of restrictive layer, these parameters were discarded due to lack of variability.

All statistics were performed with the software SAS version 9.1 (C) 2002-2003, SAS Institute, Inc.). Equal interval effects were assumed for all ordinal variables.

\section{Results}

We identified a total of 114 native species and 47 exotics in the prairie remnants. Mean richness, diversity, and dominance of exotic species values for the categorical biophysical variables are reported in Table 2. Calouse silt loam, Naff silt loam, and Larkin silt loam occurred on $<2.5 \%$ of the total plots, while NaffPalouse silt loam and Palouse-Thatuna silt loam were juxtaposed too closely on the landscape to be differentiated individually (NRCS 2005a, $2005 \mathrm{~b}$ ). These plots were excluded and we performed our linear models on the remaining 263 plots. A range of biophysical characteristics had predictive value for plot-scale metrics, as discussed below.

\section{Species Richness}

The full GLM for species richness was highly significant $(F=2.78$, df $=15, P=$ $0.0005)$, but 2 factors, aspect and vegetation structure, comprised the most predictive and efficient model $(F=8.22, \mathrm{df}=3, P<0.0001$; Table 3). Grass/forb-dominated communities contained more species than either of the shrub-dominated vegetation types (Table 2). Richness also trended higher on north-facing plots, though this effect was not significant in a post hoc regression analysis of aspect and species richness alone $\left(R^{2}=0.01, F=1.57, P\right.$ $=0.21$ ). Soil type was significant in the full model, but apparently explained very little variation and was dropped from the best model based on our AIC evaluation. Though significant, the best model explained only $9.0 \%$ of the variation in the data (Table 3). Slope, distance from edge, edge type, and the interaction of edge type and distance were not significant predictors of species richness.

\section{Simpson's Diversity Index}

The full GLM for Simpson's diversity was also highly significant $(F=2.50, \mathrm{df}=15, P=$ 0.0019 ), and a reduced model containing aspect and vegetation structure again proved the most efficient $(F=7.72, \mathrm{df}=3, P<0.0001$; Table $3)$. The highest mean diversity values were again found in grass-forb communities (Table 
TABLE 3. Full and best general linear models for the influence of biophysical variables on plot-level $(n=263)$ plant species richness, Simpson's diversity, and dominance of exotic species in 12 Palouse prairie remnants. Values of $P<0.05$ are highlighted in bold.

\begin{tabular}{|c|c|c|c|c|c|c|c|c|c|c|}
\hline & \multicolumn{5}{|c|}{ Full model } & \multicolumn{5}{|c|}{ Best model } \\
\hline & $\mathrm{AIC}^{\mathrm{d}}$ & $R^{2}$ & df & $F$ & $P$ & $\mathrm{AIC}^{\mathrm{d}}$ & $R^{2}$ & df & F & $P$ \\
\hline \multicolumn{11}{|l|}{ Species richness } \\
\hline model & 610.72 & 0.15 & 15 & 2.78 & 0.0005 & 603.88 & 0.09 & 3 & 8.22 & $<0.0001$ \\
\hline soil type & & & 4 & 3.06 & 0.0175 & & & & & \\
\hline aspect & & & 1 & 13.75 & 0.0003 & & & 1 & 5.94 & 0.0155 \\
\hline vegetation structure & & & 2 & 8.70 & 0.0002 & & & 2 & 11.48 & $<0.0001$ \\
\hline edge type & & & 3 & 2.54 & 0.0567 & & & & & \\
\hline distance to edge & & & 1 & 0.04 & 0.8454 & & & & & \\
\hline edge $*$ distance ${ }^{a}$ & & & 3 & 1.54 & 0.2056 & & & & & \\
\hline slope & & & 1 & 0.03 & 0.8659 & & & & & \\
\hline \multicolumn{11}{|l|}{ Simpson's diversityb } \\
\hline model & -1028.66 & 0.13 & 15 & 2.50 & 0.0019 & -1038.00 & 0.08 & 3 & 7.72 & $<0.0001$ \\
\hline soil type & & & 4 & 1.99 & 0.0966 & & & & & \\
\hline aspect & & & 1 & 9.33 & 0.0025 & & & 1 & 4.98 & 0.0265 \\
\hline vegetation structure & & & 2 & 8.52 & 0.0003 & & & 2 & 10.96 & $<0.0001$ \\
\hline edge type & & & 3 & 2.54 & 0.0569 & & & & & \\
\hline distance to edge & & & 1 & 0.03 & 0.8622 & & & & & \\
\hline edge $*$ distance ${ }^{a}$ & & & 3 & 3.20 & 0.0241 & & & & & \\
\hline slope & & & 1 & 0.57 & 0.4505 & & & & & \\
\hline \multicolumn{11}{|c|}{ Dominance of exotic species ${ }^{\mathrm{c}}$} \\
\hline model & -773.66 & 0.29 & 15 & 6.56 & $<0.0001$ & -777.95 & 0.28 & 12 & 8.11 & $<0.0001$ \\
\hline soil type & & & 4 & 6.70 & $<0.0001$ & & & 4 & 7.43 & $<0.0001$ \\
\hline aspect & & & 1 & 8.76 & 0.0034 & & & 1 & 8.85 & 0.0032 \\
\hline vegetation structure & & & 2 & 0.60 & 0.5514 & & & & & \\
\hline edge type & & & 3 & 3.92 & 0.0093 & & & 3 & 4.37 & 0.0051 \\
\hline distance to edge & & & 1 & 4.41 & 0.0367 & & & 1 & 4.75 & 0.0303 \\
\hline edge $*$ distance ${ }^{a}$ & & & 3 & 2.99 & 0.0316 & & & 3 & 3.39 & 0.0187 \\
\hline slope & & & 1 & 0.35 & 0.5530 & & & & & \\
\hline
\end{tabular}

aTerm for the interaction of edge type and distance from edge

bSimpson's diversity index (Simpson 1949)

cProportion of total plant cover attributed to nonnative species

cProportion of total plant cover attributed to
dAkaike's information criterion (Akaike 1974)

TABLE 4. Full and best general linear models for the influence of soil characteristics on plot-level $(n=60)$ plant species richness, Simpson's diversity index, and dominance of exotic species in 6 Palouse prairie remnants. Values of $P$ $<0.05$ are highlighted in bold.

\begin{tabular}{|c|c|c|c|c|c|c|c|c|c|c|}
\hline & \multicolumn{5}{|c|}{ Full Model } & \multicolumn{5}{|c|}{ Best Model } \\
\hline & $\mathrm{AIC}^{\mathrm{c}}$ & $R^{2}$ & $\mathrm{df}$ & $F$ & $P$ & $\mathrm{AIC}^{\mathrm{c}}$ & $R^{2}$ & $\mathrm{df}$ & $F$ & $P$ \\
\hline $\begin{array}{l}\text { Species richness } \\
\text { model }\end{array}$ & 127.81 & 0.05 & 6 & 0.42 & 0.8648 & & & & & \\
\hline $\begin{array}{l}\text { Simpson's diversity } \\
\text { model }\end{array}$ & -228.65 & 0.15 & 6 & 1.25 & 0.2988 & & & & & \\
\hline $\begin{array}{l}\text { Dominance of exotic species }{ }^{b} \\
\text { model }\end{array}$ & -200.62 & 0.32 & 6 & 3.39 & 0.0079 & -204.62 & 0.31 & 4 & 5.10 & 0.0018 \\
\hline soil type & & & 3 & 5.34 & $\mathbf{0 . 0 0 3 2}$ & & & 3 & 6.79 & 0.0007 \\
\hline $\begin{array}{l}\text { depth of A-horizon } \\
\text { depth to restrictive layer }\end{array}$ & & & $\begin{array}{l}1 \\
1\end{array}$ & $\begin{array}{l}0.30 \\
2.42\end{array}$ & $\begin{array}{l}0.8870 \\
0.1270\end{array}$ & & & 1 & 5.12 & 0.0286 \\
\hline rock fragments & & & 1 & 0.20 & 0.6601 & & & & & \\
\hline
\end{tabular}

aSimpson's diversity index (Simpson 1949)

bProportion of total plant cover attributed to nonnative species

cAkaike's information criterion (Akaike 1974)

2) on northerly slopes, though the aspect relationship was not significant in a post-hoc regression analysis $\left(R^{2}=0.01, F=1.17, P=\right.$ 0.28 ). While the interaction between edge type and distance from edge was significant in the full model, it did not explain enough variation to justify inclusion in the best model, based on AIC analysis. The best model explained 8.0\% 
of the variation in the data (Table 3). Slope and soil type appeared to have no impact on diversity in any model.

\section{Dominance of Exotic Species}

The full GLM for dominance of exotic species was highly significant $(F=6.56, \mathrm{df}=$ $15, P<0.0001)$, and a 5 -factor reduced model had the best fit to the data $(F=8.11, \mathrm{df}=12$, $P<0.0001$; Table 3). Soil type and aspect were significant in the best model, as were the distance from edge, edge type, and their interaction. The lowest mean dominance of exotic species occurred on northern-facing slopes, a significant relationship even in a stand-alone post-hoc regression $\left(R^{2}=0.15, F=46.63, P\right.$ $<0.001)$. Plots with agricultural fields as the nearest matrix habitat had the lowest mean dominance of exotics (Table 2), but the significant interaction term implies this effect is intertwined with distance from edge. Slope and vegetation structure had no impact on the dominance of exotics.

\section{Additional Soil Characteristics}

Soil characteristics alone did not have predictive value in GLMs for either species richness $(F=1.94$, $\mathrm{df}=11, P=0.0574)$ or Simpson's diversity $(F=1.80, \mathrm{df}=11, P=0.0810$; Table 4). For dominance of exotic species, however, both the full model $(F=3.95$, df $=$ $11, \mathrm{P}<0.0001)$ and a reduced, 2-parameter model $(F=5.03, \mathrm{df}=9, P<0.0001)$ were highly significant. The best model included soil type and depth to restrictive layer, and explained $31.0 \%$ of the variation in the data (Table 4).

\section{Discussion}

Our results met the prediction that biophysical characteristics influence the structure of plant communities in Palouse prairie. We found several biophysical variables that had significant power to predict plot-scale species richness, Simpson's diversity, and dominance of exotic species, though all models left a great deal of unexplained variation. Additional soil data confirmed that the depth to restrictive layer influenced the dominance of exotic species. These findings may be useful in predicting habitat quality and restoration potential of scattered, isolated, and largely undocumented remnants of endangered Palouse prairie.

\section{Species Richness and Simpson's Diversity Index}

Numerous studies have documented associations between aspect and the composition of prairie plant communities (Albertson 1937, Hanson and Whitman 1938). Our models found aspect to be an important variable, with the most species-rich and diverse plots occurring on north-facing slopes. Harrison (1999) also found high plant diversity on north-facing slopes in a California grassland, though Hutchings (1983) noted no difference in diversity related to aspect in English chalk grasslands. It is likely that patterns are landscape-specific and influenced by local factors, including disturbance history (Collins et al. 2002, Maestre 2004). In Palouse prairie many of the southfacing sites are on larger ridge-top remnants with a history of grazing, while small, northfacing patches can be embedded in agricultural fields with a much different disturbance regime. The role of aspect in exotic species dominance also influences overall species richness and diversity, as discussed below.

Vegetation structure is often linked to the diversity of plant species (Baer et al. 2005, Lett and Knapp 2005), and our finding that grass/forb communities are more rich and diverse than low- or high-shrub dominated sites matches earlier descriptions of Palouse prairie (Daubenmire 1970, Klepeis 2001). This pattern has conservation implications, as shrubdominated communities often supplant grass/ forb communities in landscapes where fires are suppressed (e.g., Heisler et al. 2003). Though historic rates of Native American and natural burning on the Palouse are debated (Daubenmire 1970, Boyd 1999), it is agreed that fires are less frequent since European settlement (Morgan et al. 1996), and Klepeis (2001) has noted trends toward increasing shrub cover at several Palouse prairie sites.

Other biophysical variables were not significant in our models. Slope, an important parameter for some plant communities (e.g., Bennie et al. 2006), appears relatively unimportant to the community structure for our plot-level Palouse prairie data. Its potential role may be obscured by the relative absence of level or modestly sloping sites in this study - much of the remaining Palouse prairie habitat lies on steep land. Edge effects have been associated with altered plant diversity in other grassland studies (e.g., Quinn and Robinson 1987), but 
they had little impact on the diversity of our plots. It could be that these prairie patches have relatively "hard" edges, but it should also be noted that our plots were placed randomly within sites, not along a strict edge-to-interior gradient that might have picked up more-subtle trends. Finally, while soil type often influences prairie plant communities (Albertson 1937, Hanson and Whitman 1938), it had little predictive value for richness and diversity metrics here.

\section{Dominance of Exotic Species}

The influence of aspect on the dominance of exotic species has been noted in several studies (e.g., Harrison 1999, Bennie et al. 2006), but the trends are sometimes contradictory. Harrison (1999) documented higher native plant diversity and lower incidence of exotics on north-facing plots in California grasslands, the same pattern noted in our study. The annual grass Bromus tectorum, one of the most common exotic species at our sites, may be partially responsible for these results: it has been strongly associated with south-facing slopes at other sites nearby (Rickard 1975). On the other hand, Bennie et al. (2006) proposed that south-facing slopes in English chalk grasslands are more resistant to invasion by exotic species. As noted for richness and diversity, it is likely that local factors, particularly land use and disturbance history, play an important role in the dominance of exotic species.

The type of adjacent matrix habitat also impacted exotic species dominance, with lower prevalence of exotics in remnants adjacent to active agricultural fields. This contradicts an earlier study of hedgerows and woodlot margins (Boutin and Jobin 1998), where intensive farming practices were associated with increases in weedy exotics in neighboring habitats. At our sites, however, it appears possible that the control of weeds in agricultural fields may be helping to prevent their establishment in adjacent prairie, a possibility worthy of further study.

Other biophysical variables had varying impacts on exotic species dominance. Soil type was a significant predictor in our models, but no individual soil type was significantly different from the others (see Table 2). Specific soil characters are often linked to the prevalence of exotic species, however (e.g., Stohlgren et al. 1999), as discussed in detail below. Vegeta- tion structure did not impact exotic species dominance at our sites; it appears that grass/ forb, low-shrub, and high-shrub communities were all equally susceptible to the introduction of nonnatives. As noted above, slope was not an important predicting variable in these models.

\section{Additional Soil Characteristics}

Additional sampling determined that soil type and depth to a restrictive layer both had strong implications for the dominance of exotic species. A-horizon depth has been linked with plant community structure in tallgrass prairie (Bliss and Cox 1964). On the other hand, Baer et al. (2005) found no direct link between soil depth and plant diversity in experimental prairie treatments, and MacDougall et al. (2006) found no relationship between soil depth and the prevalence of invasive exotic species in California savanna grasslands. These inconsistent results and the relatively low predictive power of our models could suggest that our soil data were insufficient to identify specific soil characteristics affecting plant communities.

Numerous studies have demonstrated the importance of water and nutrient availability to plant community structure (Greig-Smith 1979, Burke et al. 1998) and the prevalence of invasive exotic species (Vinton and Georgen 2006). Soil characteristics that can affect water content and nutrient availability include percent clay, textural class, mineralogy, organic matter content, nutrient status, drainage, and soil depth. Soil biological factors can also influence plant diversity (Bever et al. 1997), and the presence of cryptogamic crusts has been shown to influence nitrogen fixation, soil hydrological processes, and the establishment of exotic species (Hilty et al. 2004). Our soil measurements did not include any of these parameters, but descriptions in the NRCS Soil Survey Data base (NRCS 2005a, 2005b) suggest that they can vary widely among Palouse prairie soil types. The north-facing silt loam soils associated with high native plant dominance, for example, are very likely to provide greater available water than soils with higher gravel and rock fragment content found on south-facing aspects. These variables clearly deserve further consideration in future studies.

\section{Limitations}

The trends emerging from this data merit a larger-scale effort and we believe the standard 
sampling and statistical methods used herein can be easily replicated in additional sites. One note of caution, however, is the lack of a metric for disturbance history in our models. Palouse prairie remnants have been impacted by a variety of human disturbances (e.g., grazing, fire, herbicide drift) at varying intensities (Weddell and Lichthardt 1998). Disturbance has repeatedly been shown to impact plant community structure in grasslands (Coffin and Lauenroth 1988, Maestre 2004) and in some cases may overwhelm the effects of biophysical variables (Naeem et al. 2000). Lack of consistent and reliable land-use history data on these sites prevented the inclusion of a disturbance variable in this study. Disturbance history is probably an important factor influencing Palouse prairie plant communities, however, and efforts should be made to include it in future research.

\section{Conclusions}

Northern-facing plots in grass/forb communities appeared to have the highest species richness and diversity and the lowest dominance of exotic species in this study. Dominance of exotics also trended low for plots near active agricultural fields and on soils with deep surface layers. These results represent the 1st model-based study linking Palouse prairie plant communities to specific soil and biophysical variables. They may have direct application in identifying conservation and restoration priorities for this endangered and littlestudied ecosystem.

\section{ACKNOWLEDGMENTS}

This work was funded in part by NSFIGERT Grant 0114304. The authors thank Chris Looney, Shannon Donovan, Nilsa A. Bosque-Perez, Sanford Eigenbrode, J.D. Wulfhorst, Timothy Prather, and Paul McDaniel for their suggestions and support, and Karl Umiker, Eliza Habegger, and Manuel Diaz-Gonzalez for their help in the field.

\section{Literature Cited}

AKaIKE, H. 1974. A new look at the statistical model identification. IEEE Transactions on Automatic Control 19:716-723.

ALbertson, F.W. 1937. Ecology of mixed grass prairie in west central Kansas. Ecological Monographs 7:481547.
Atauri, J.A., AND J.V. DE LuCio. 2001. The role of landscape structure in species richness distribution of birds, amphibians, reptiles and lepidopterans in Mediterranean landscapes. Landscape Ecology 16:147-159.

BaER, S.G., S.L. COLLINS, J.M. BLAir, A.K. KNAPP, AND A.K. FIEDLER. 2005. Soil heterogeneity effects on tallgrass prairie community heterogeneity: an application of ecological theory to restoration ecology. Restoration Ecology 13:413-424.

Boyd, R. 1999. Indians, fire and the land in the Pacific Northwest. Oregon State University Press, Corvallis.

Bennett, A.F., J.Q. Radford, and A. Haslem. 2006. Properties of land mosaics: implications for nature conservation in agricultural environments. Biological Conservation 133:250-264.

Bennie, J., M.O. Hill, R. BaXter, and B. Huntley. 2006. Influence of slope and aspect on long-term vegetation change in British chalk grasslands. Journal of Ecology 94:355-368.

Bever, J.D., K.M. Westover, and J. Antonovics. 1997. Incorporating the soil community into plant population dynamics: the utility of the feedback approach. Journal of Ecology 85:561-573.

BLISS, L.C., AND G.W. Cox. 1964. Plant community and soil variation within a northern Indiana prairie. American Midland Naturalist 71:115-128.

Boutin, C., AND B. JoBIN. 1998. Intensity of agricultural practices and effects on adjacent habitats. Ecological Applications 7:544-557.

Bowles, M.L., P.D. Kelsey, and J.L. McBride. 2005. Relationships among environmental factors, vegetation zones and species richness in a North American calcareous prairie fen. Wetlands 25:685-696.

Brye, K.R., C.P. WEST, AND E.E. GBuR. 2004. Soil quality differences under native tallgrass prairie across a climosequence in Arkansas. American Midland Naturalist 152:214-230.

Buol, S.W., R.J. Southard, R.C. Graham, and P.A. MCDANIEL. 2003. Soil genesis and classification. Iowa State University Press, Ames.

Burke, I.C., W.K. Lauenroth, M.A. Vinton, P.B. Hook, R.H. Kelly, H.E. Epstein, M.R. Aguiar, et aL. 1998. Plant-soil interaction in temperate grasslands. Biogeochemistry 41:121-143.

Coffin, D.P., AND W.K. Lauenroth. 1988. The effects of disturbance size and frequency on a shortgrass plant community. Ecology 69:1609-1617.

Collins, S.L., S.M. GLENN, AND J.M. BRIGGS. 2002. Effects of local and regional processes on plant species richness in tallgrass prairie. Oikos 99:571-579.

Daubenmire, R. 1959. A canopy-coverage method of vegetational analysis. Northwest Science 33:43-64.

. 1970. Steppe vegetation of Washington. Washington Agricultural Experimental Station, Pullman.

Fischer, J., D.B. Lindenmayer, And I. Fazey. 2004. Appreciating ecological complexity: habitat contours as a conceptual landscape model. Conservation Biology 17:1245-1253.

Greig-Smith, P. 1979. Pattern in vegetation. Journal of Ecology 67:755-779.

Hanson, H.C., and W. Whitman. 1938. Characteristics of major grassland types in western North Dakota. Ecological Monographs 7:57-114.

Harrison, S. 1999. Native and alien species diversity at the local and regional scales in a grazed California grassland. Oecologia 121:99-106.

Heisler, J.L., J.M. Briggs, AND A.K. KNapp. 2003. Longterm patterns of shrub expansion in a $\mathrm{C}_{4}$-dominated 
grassland: fire frequency and the dynamics of shrub cover and abundance. American Journal of Botany 90:423-428.

Hilty, J.H., D.J. Eldridge, R. Roesntretter, M.C. WiCKLOW-Howard, AND M. PELLANT. 2004. Recovery of biological soil crusts following wildfire in Idaho. Rangeland Ecology and Management 57:89-96.

Huenneke, L.F., S.P. Hamburg, R. Koide, H.A. Mooney, AND P.M. Vitousek. 1990. Effects of soil resources on plant invasion and community structure in Californian serpentine grassland. Ecology 71:478-491.

Hutchings, M.J. 1983. Plant diversity in four chalkland grassland sites with different aspects. Plant Ecology 53:179-189.

KLEPEIS, D.M. 2001. Structure and susceptibility of steppe to biotic invasion: re-analysis of permanent plots. Master's thesis, Washington State University, Pullman.

Kramer, C.Y. 1956. Extension of multiple range tests to group means with unequal sample sizes. Biometrics 11:307-310.

LETT, M.S., AND A.K. KNAPP. 2005. Woody plant encroachment and removal in mesic grassland: production and composition responses of herbaceous vegetation. American Midland Naturalist 153:217-231.

Lichthardt, J., AND R.K. Moseley. 1997. Status and conservation of the Palouse grassland in Idaho. U.S. Fish and Wildlife Service, Boise, ID.

MacDougall, A.C., J. Boucher, R. Turkington, and G.E. BRADFIELD. 2006. Patterns of plant invasion along an environmental stress gradient. Journal of Vegetation Science 17:47-56.

Maestre, F. 2004. On the importance of patch attributes, environmental factors and past human impacts as determinants of perennial plant species richness and diversity in Mediterranean semiarid steppes. Diversity and Distributions 10:21-29.

McDonald, E.V., AND A.J. BusaCCA. 1988. Record of prelate Wisconsin giant floods in the Channeled Scabland interpreted from loess deposits. Geology 16: 728-731.

McLachlan, S.M., AND A.L. KNISPEL. 2005. Assessment of long-term tallgrass prairie restoration in Manitoba, Canada. Biological Conservation 124:75-88.

Morgan, P., S.C. Bunting, A.E. Black, T. Merrill, and S. BARRETT. 1996. Fire regimes in the Interior Columbia River Basin: past and present. Final Report, RJVAINT-94913, Intermountain Fire Sciences Laboratory, USDA Forest Service, Intermountain Research Station, Missoula, MT.

Naeem, S., J.M.H. Knops, D. Tilman, K.M. Howe, T. Kennedy, and S. Gale. 2000. Plant diversity increases resistance to invasion in the absence of covarying extrinsic factors. Oikos 91:97-108.

Noss, R., J. Strittholt, G. Orians, and J. Adams. 1997. Palouse grasslands. Pages 275-276 in T. Ricketts, editor, Terrestrial ecoregions of North America: a conservation assessment. Island Press, Washington, DC.

NRCS. 2005a. Soil Survey Geographic (SSURGO) Database for Latah County area, Idaho. U.S. Department of Agriculture, Natural Resources Conservation Service, Fort Worth, TX.

2005b. Soil Survey Geographic (SSURGO) Database for Whitman County, WA. U.S. Department of Agriculture, Natural Resources Conservation Service, Fort Worth, TX.

Pino, J., F. Roda, J. Ribas, and X. Pons. 2000. Landscape structure and bird species richness: implications for conservation in rural areas between natural parks. Landscape and Urban Planning 49:35-48.

Polley, H.W., J.D. Derner, and B.J. Wilsey. 2005. Patterns of plant species diversity in remnant and restored tallgrass prairies. Restoration Ecology 13: 480-487.

Quinn, J.F., And G.R. Robinson. 1987. The effects of experimental subdivision on flowering plant diversity in a California annual grassland. Journal of Ecology $75: 837-856$.

RICKARD, W.H. 1975. Vegetation of knob and kettle topography in south-central Washington. Northwest Science 49:147-152.

SAMSON, F.B., AND F.L. KNOPf. 1996. Prairie conservation: preserving North America's most endangered ecosystem. Island Press, Washington, DC.

Simpson, E.H. 1949. Measurement of diversity. Nature 163:688.

Soil Survey Division Staff. 1993. Soil survey manual. Soil Conservation Service. U.S. Department of Agriculture Handbook 18.

Sperber, T.D., J.M. Wraith, and B.E. Olson. 2003. Soil physical properties associated with the invasive spotted knapweed and native grasses are similar. Plant and Soil 251:241-249.

Steinauer, E.M., AND S.L. Collins, 1995. Effects of urine deposition on small-scale patch structure in prairie vegetation. Ecology 76:1195-1205.

SteineR, N.C., AND W. KoHLER. 2003. Effects of landscape patterns on species richness-a modeling approach. Agriculture, Ecosystems and Environment 97:353361.

Stohlgren, T.J., L.D. Schell, and B. Vanden Heuvel. 1999. How grazing and soil quality affect native and exotic plant diversity in Rocky Mountain grasslands. Ecological Applications 9:45-64.

TukeY, J.W. 1953. The problem of multiple comparisons. Unpublished manuscript.

Vinton, M.A., And E.M. Georgen. 2006. Plant-soil feedbacks contribute to the persistence of Bromus inermis in tallgrass prairie. Ecosystems 9:967-976.

Weddell, B.J. 2001. Restoring Palouse and canyon grasslands: putting back the missing pieces. Bureau of Land Management Technical Bulletin 01-15, Cottonwood, ID.

WedDELL, B.J., AND J. LichthaRdT. 1998. Identification of conservation priorities for and threats to Palouse grassland and canyon grassland remnants in Idaho, Washington, and Oregon. Bureau of Land Management Technical Bulletin 98-13, Cottonwood, ID.

White, R., S. Murray, and M. Rohweder. 2000. Pilot analysis of global ecosystems: grassland ecosystems. World Resources Institute, Washington, DC.

Wilsey, B.J., L.M. Martin, AND H.W. Polley. 2005. Predicting plant extinction based on species-area curves in prairie fragments with high beta richness. Conservation Biology 19:1835-1841.

Wilson, J.B., T.C.E. Wells, I.C. Trueman, G. Jones, M.D. Atkinson, M.J. Crawley, M.E. Dodd, and J. SilVERTOWN. 1996. Are there assembly rules for plant species abundance? An investigation in relation to soil resources and successional trends. Journal of Ecology 84:527-538.

Received 14 September 2007 Accepted 24 January 2008 